\title{
POTENTIAL WATER CONSERVATION USING SITE-SPECIFIC VARIABLE RATE IRRIGATION
}

\author{
K. C. Stone, P. J. Bauer, G. C. Sigua
}

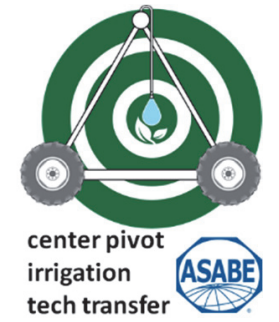

Collection

\begin{abstract}
Site-specific variable-rate irrigation (VRI) systems can be used to spatially manage irrigation within sub-fieldsized zones and optimize spatial water use efficiency. The goal of the research is to provide farmers and consultants a tool to evaluate the potential benefits of implementing VRI. The specific objective of this research is to evaluate the potential water savings using VRI management compared with uniform irrigation management to maintain soil water holding capacity above 50\% depletion using two irrigation scenarios: 1) a standard $12.5 \mathrm{~mm}$ irrigation per application; and 2) an application to refill the soil profile to field capacity. A 21-year simulation study was carried out on a selected field with varying degrees of soil and topographic variability. The simulated field had 12 soil mapping units with water holding capacities in the top 0.30-m ranging from 42 to $70 \mathrm{~mm}$. The 21-year simulation covering all weather conditions for each soil produced only two significantly different irrigation management zones for scenario 1, and for scenario 2 only one management zone. However, when the 21-year period was divided into periods with different ratios of rainfall to reference evapotranspiration, the simulations identified 1 to 5 management zones with significantly different irrigation requirements. These results indicate that variable rate irrigation system design and management should not be solely based on long term average weather conditions. Years with differing weather conditions should be used for potentially identifying management zones for VRI systems. Irrigation application depths between management zones ranged from 17 to $38 \mathrm{~mm}$. However, when the actual soil areas of the study field were utilized to calculate the total volume of irrigation water applied, it resulted in an increase in water usage in the 2 and 4 management zones ranging from -1.2\% to 5.8\%. Water usage with VRI over uniform irrigation was greater by $-1.6 \%$ to $6.8 \%$ in the $12.5 \mathrm{~mm}$ irrigations and by $-1.2 \%$ to $2.2 \%$ for the field capacity irrigations
\end{abstract}

Keywords. Management zones, Precision farming, Variable-rate irrigation, Water conservation.

$\mathrm{V}$ ariable rate irrigation (VRI) systems have the potential to conserve water by spatially allocating limited water resources. Spatial water applications attempt to overcome site-specific problems that include spatial variability in topography, soil type, soil water availability, and landscape features. The VRI systems can apply water to crops based on spatial crop requirements, thus, they may be an important asset in fields that have highly variable soil with different water holding capacities.

(c) (1) (9) $\Theta$

The authors have paid for open access for this article. This work is licensed under a Creative Commons AttributionNonCommercial-NoDerivatives 4.0 International License https://creative commons.org/licenses/by-nc-nd/4.0/

Submitted for review in September 2018 as manuscript number NRES 13108; approved for publication as part of the Center-Pivot Irrigation Tech Transfer Collection by the Natural Resources \& Environmental Systems Community of ASABE in February 2019.

Mention of company or trade names is for description only and does not imply endorsement by the USDA. The USDA is an equal opportunity provider and employer.

The authors are Kenneth C. Stone, Research Agricultural Engineer, Philip J. Bauer, Research Agronomist, and Gilbert C. Sigua, Research Soil Scientist, USDA-ARS Coastal Plains Soil, Water, and Plant Research Center, Florence, South Carolina. Corresponding author: Kenneth C. Stone, USDA-ARS, 2611 West Lucas Street, Florence, SC 29501; phone: 843-669-5203; e-mail: ken.stone@ars.usda.gov.
Recent droughts throughout the United States have highlighted the delicate balance that faces agricultural production in competition with urban, industry, and environmental water uses (Stone et al., 2010). Under these drought conditions, VRI systems may be utilized for water conservation. Sadler et al. (2005) outlined opportunities for conservation including situations where non-cropped areas exist in a field for which irrigation can be turned completely off; situations where a reduced irrigation amount provides specific benefits; and finally, situations where optimizing irrigation amount to adapt to spatial productivity provides quantitative benefits.

Water conservation using VRI systems has been demonstrated in situations where water is shut off in response to physical features and to reduce the overlap from one system to another (Sadler et al., 2005). In these situations, water conservation would be impacted by the extent of the noncropped areas or the amount of irrigation system overlap. Non-cropped areas may include rock outcrops, field ditches, wetlands or depressions included in the field, and field roads or public roads adjacent to irrigation fields. In production fields, they also addressed the potential of VRI to adapt to spatial soil infiltration rates and soil water storage capacities to avoid runoff or potential ponding in field portions. Water 
collected or ponded in lower lying areas is likely to be a major contributor to nutrient leaching and may create unfavorable growing conditions. Additionally, runoff due to excess irrigation could result in sediment transport offsite or relocation within the field area.

Although VRI systems have been shown to conserve water in the examples above, there is little scientific information documenting the capability of a VRI system to conserve water for crop production (Evans et al., 2013). A few multi-season field studies investigated the potential water savings using VRI versus Uniform irrigation (UI). In Idaho, King et al. (2006) compared VRI to UI in potato production over two years and found no significant difference in yield or water use. In the first year of their study, VRI treatment water application depths ranged from $14 \%$ less irrigation water applied to $19 \%$ greater irrigation water applied. In the second year, VRI treatment water application depths ranged from $18 \%$ less to $10 \%$ greater water application. In Mississippi, Sui and Yan (2017) compared VRI and UI for corn and soybean production and reported VRI used $25 \%$ less water with no overall significant difference in yields.

Most studies evaluating the benefits of VRI have utilized modeling efforts to compare crop yields under VRI and conventional UI management. In Evans and King (2012), they reported on several simulation studies examining crop production under both VRI and UI. Using 30 years of climate data, Ritchie and Amato (1990) simulated water use and corn yields for VRI and UI based on low, intermediate, and high soil water holding capacity management zones. They found that UI resulted in yield losses and/or excessive water applications due to under irrigation in some areas and over irrigating in other areas. They concluded VRI was a better management option based on yields, but it did not result in overall water savings. In Georgia, Nijbroek et al. (2003) conducted a 25 -year soybean simulation study comparing VRI and UI for water use, drainage, and yields. They used five irrigation management zones based on soil available water holding capacity. Although there were yearly differences in irrigation amounts, overall for the 25-year study, there were not significant differences in yield, water use, or drainage. In Germany, Al-Kufaishi et al. (2006) used a daily soil water balance model to simulate water use for sugar beet production with management zones delineated based on soil available water holding capacity. Using 20 -mm applications per required irrigation, they reported $13 \%$ lower water usage in VRI versus UI. In New Zealand, Hedley and Yule (2009) reported VRI water savings of $20 \%$ to $26 \%$ compared to UI in a three-year simulation on pasture and corn fields.

In a three-year combined field and spatial interpolation study, Sadler et al. (2002) measured the yield response of corn to irrigation across soil mapping units under a 6-ha VRI system. They used the spatially measured yield response to extrapolate the potential water savings using VRI management. They developed spatial soil-specific water production functions and extrapolated whole-field responses to various irrigation application rates. They reported a mean water savings of $8 \%$ from actual UI irrigation practices. Additionally, they calculated VRI water savings of $19 \%$ compared to ideal
UI water management practices and $21 \%$ for a yield-maximizing UI practice (Sadler et al., 2005).

In this research, we used the field site from Sadler et al. (2002) to evaluate the potential for water conservation with VRI using a water balance approach. The field site had 12 soil mapping units with highly variable soils. Our specific objective was to evaluate the potential water savings using VRI management compared to uniform irrigation (UI) management using a simple water balance modeling approach. We evaluated and compared UI management with VRI management with two and four management zones, and also using the 12 individual soil types as individual management zones.

\section{METHODS}

\section{FIELD SITE DESCRIPTIONS}

A 6-ha field with highly variable soils and a history of spatially managed crop production was selected to simulate water requirements for a corn crop (Sadler et al., 2002). Soil at this site had been mapped on a $1: 1200$ scale by USDANRCS staff in 1984 (USDA-SCS, 1984; fig. 1). Brief descriptions of the 12 soil map units are shown in table 1 . The water holding capacity for these soils was estimated using the soil properties in the DSSAT soils database (Jones et al., 2003), from previous modeling research by Sadler et al. (2000), and from Peele et al. (1970). The soil had a wide range of water holding capacities (table 1). The water holding capacities in the top $0.30-\mathrm{m}$ of the soils ranged from approximately 42 to $70 \mathrm{~mm}$. We assumed that each soils' potential productivity was equal in these simulations.

\section{Crop Management Simulation}

These soils were used in a 21-year water balance simulation to maintain adequate soil moisture in the top $0.30 \mathrm{~m}$ of

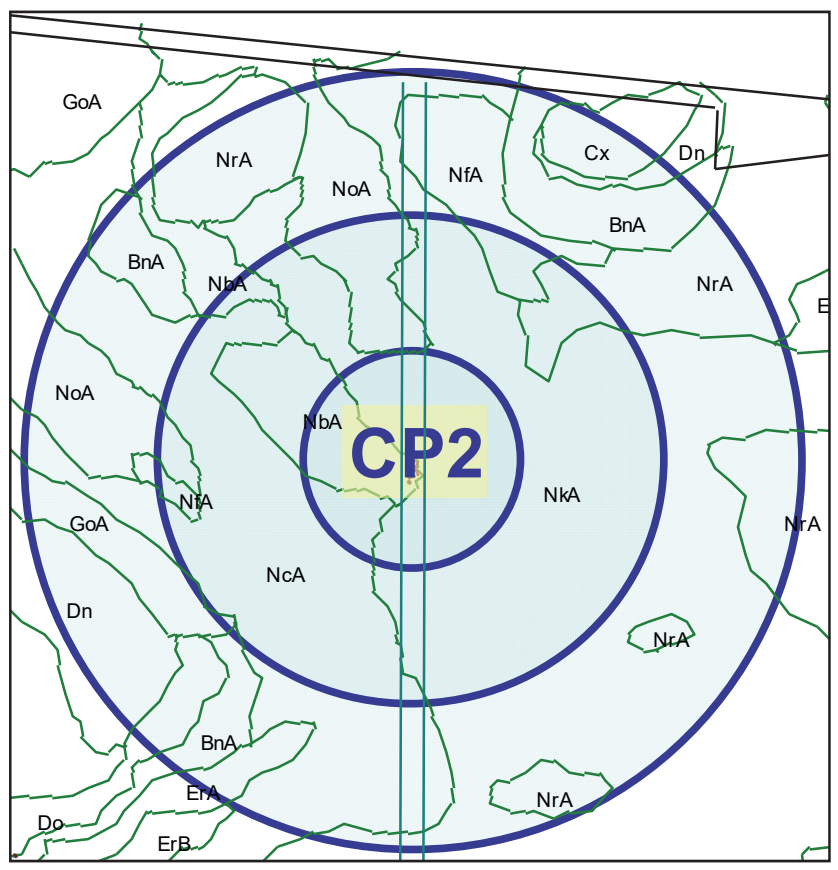

Figure 1. Diagram of field site with highly variable soils used in the simulation study. 
Table 1. Description of soils and soil properties in the top 0.3-m located under the variable-rate irrigation system at Florence, SC (after Sadler et al., 2002).

\begin{tabular}{|c|c|c|c|c|c|c|}
\hline Symbol & Soil Classification & $\begin{array}{c}\text { Water Holding } \\
\text { Capacity } \\
(\mathrm{mm})\end{array}$ & $\begin{array}{l}\text { Field Capacity } \\
\left(\mathrm{m}^{3} / \mathrm{m}^{3}\right)\end{array}$ & $\begin{array}{c}\text { Wilting Point } \\
\left(\mathrm{m}^{3} / \mathrm{m}^{3}\right)\end{array}$ & $\begin{array}{c}\text { Saturation } \\
\left(\mathrm{m}^{3} / \mathrm{m}^{3}\right)\end{array}$ & $\begin{array}{c}\text { Field area } \\
\left(\mathrm{m}^{2}\right)\end{array}$ \\
\hline $\mathrm{BnA}$ & Bonneau loamy fine sand (lfs), $0 \%$ to $2 \%$ slopes & 42.3 & 0.121 & 0.045 & 0.277 & 3205.8 \\
\hline $\mathrm{Cx}$ & Coxville loam & 67.6 & 0.254 & 0.133 & 0.336 & 659.0 \\
\hline Dn & Dunbar lfs & 60.0 & 0.169 & 0.073 & 0.295 & 2299.5 \\
\hline Do & Dunbar lfs, overwash & 59.5 & 0.169 & 0.073 & 0.295 & 665.00 \\
\hline ErA & Emporia fine sandy loam (fsl), $1 \%$ to $2 \%$ slopes & 59.5 & 0.156 & 0.056 & 0.270 & 555.6 \\
\hline GoA & Goldsboro $1 \mathrm{fs}, 0 \%$ to $2 \%$ slopes & 69.8 & 0.170 & 0.061 & 0.27 & 1291.4 \\
\hline $\mathrm{NbA}$ & Noboco lfs, moderately thick surface, $0 \%$ to $2 \%$ slopes & 57.7 & 0.153 & 0.056 & 0.261 & 2898.3 \\
\hline $\mathrm{NcA}$ & Noboco lfs, thick surface, $0 \%$ to $2 \%$ slopes & 42.8 & 0.145 & 0.055 & 0.261 & 10992.6 \\
\hline NfA & Noboco fsl, $1 \%$ to $2 \%$ slope & 50.7 & 0.206 & 0.11 & 0.301 & 2251.2 \\
\hline $\mathrm{NkA}$ & Norfolk lfs, moderately thick surface, $0 \%$ to $2 \%$ slopes & 49.3 & 0.137 & 0.056 & 0.260 & 22639.2 \\
\hline NoA & Norfolk lfs, thick surface, $0 \%$ to $2 \%$ slopes & 47.5 & 0.125 & 0.053 & 0.26 & 4198.8 \\
\hline $\mathrm{NrA}$ & Norfolk fsl, $1 \%$ to $2 \%$ slopes & 42.8 & 0.238 & 0.144 & 0.327 & 5919.7 \\
\hline
\end{tabular}

the soil profile. Based on past experiences, it was estimated that the maximum allowable soil water depletion level for corn production in the region was $50 \%$. Two irrigation scenarios were simulated when the maximum allowable water depletion level occurred: 1) a 12.5-mm irrigation was applied; and 2) an irrigation to refill the soil profile to field capacity. The daily simulated water balance was calculated as:

$$
\mathrm{S}_{\mathrm{i}+1}=\mathrm{S}_{\mathrm{i}}+\mathrm{R}_{\mathrm{i}}+\mathrm{I}_{\mathrm{i}}-\mathrm{ET}_{\mathrm{ci}}-\mathrm{RO}_{\mathrm{i}}-\mathrm{D}_{\mathrm{i}}
$$

where i represents the day, $\mathrm{S}$ was the soil water storage, $\mathrm{R}$ was the rainfall, I was the irrigation, $\mathrm{ET}_{\mathrm{c}}$ the crop evapotranspiration, RO the runoff, and D the drainage. In the simulation, when the soil storage exceeded saturation, the excess was considered runoff. Drainage was calculated as the difference between maximum soil water holding capacity (field capacity) and saturation. Crop evapotranspiration was calculated based on the ASCE standardized reference evapotranspiration ( $E T_{0}$ ) equation (Allen et al., 2005) method for short grass and crop coefficients for a corn crop. The field corn crop coefficients used in the simulations were $\mathrm{K}_{\mathrm{cb} \text { init }}=0.15$, $\mathrm{K}_{\mathrm{cb} \text { mid }}=1.15$, and $\mathrm{K}_{\mathrm{cb} \text { end }}=0.5$ (FAO-56: Allen et al., 1998). The weather parameters were collected from an on-site weather station. In the simulations, the growing season was from 31 March to 6 August. The growing season rainfall was highly variable during the 21 -year simulation period (fig. 2) and encompassed both wet and drought years. To account

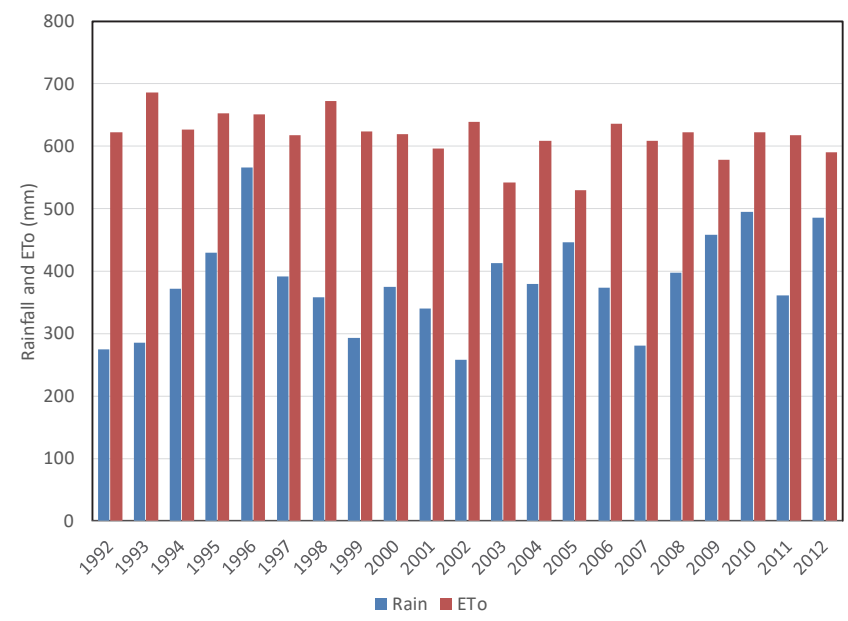

Figure 2. Cumulative seasonal rainfall and potential evapotranspiration (ETo) for the 21-year study period in Florence, South Carolina. for highly variable growing season rainfall, we calculated the ratio of growing season cumulative rainfall to cumulative $\mathrm{ET}_{\mathrm{o}}$ (Rainfall/ $\mathrm{ET}_{\mathrm{o}}$ ). In addition to simulations covering all years, we estimated the irrigation requirements for years with the Rainfall/ET $\mathrm{ET}_{\mathrm{o}}$ ratios of $<50 \%, 50 \%$ to $60 \%, 60 \%$ to $75 \%$, and $>75 \%$. The years with Rainfall/ $/ \mathrm{ET}_{0}$ ratio $<50 \%$ were 1992, 1993, 1999, 2002, and 2007. The years with Rainfall/ET $\mathrm{ET}_{\mathrm{o}}$ ratio between $50 \%$ and $60 \%$ were 1994,1998 , 2001, 2006, and 2011. The years with Rainfall/ET ratio be- $^{-}$ tween $60 \%$ and $75 \%$ were $1995,1997,2000,2004$, and 2008. The years with Rainfall/ET ratio $>75 \%$ were 1996 , 2003, 2005, 2009, 2010, and 2012.

\section{Management Zones}

To simulate the VRI crop management of the field site, we used four irrigation scenarios. These irrigation scenarios included: 1) simulations using each individual soil mapping unit as a management zone; 2) simulations using two management zones grouping soils with similar water holding capacities (zone 1: BnA, NcA, NrA, NoA, NfA, NkA and zone 2: NbA, ErA, Dn, Cx, GoA); 3) simulations with four management zones (zone 1: BnA, NcA, NrA; zone 2: NoA, NkA, NfA; zone 3: NbA; zone 4: ErA, Dn, Cx, GoA). Since the Dn and Do soils had approximately the same water holding capacity, they were combined for the simulations. These simulations of various management zones were then compared to 4) a uniform irrigation using the soil type with the largest area in the field to control irrigation applications. All irrigation simulations started with a planting date of 31 March (day of year 90) and ended on 6 August (day of year 218).

\section{Statistical Analyses}

All simulation results were analyzed in SAS (SAS Institute, Inc. Cary, N.C.) using Proc GLM. The analyses compared the irrigation water applied for each soil and irrigation means were separated using the Waller-Duncan k-ratio and Fisher's least significant (LSD) tests at the $95 \%$ confidence level.

\section{RESULTS}

\section{SCENARIO 1, $12.5 \mathrm{~mm}$ IRRIGATION}

The simulation results for the individual soils over the 21year period produced irrigation amounts ranging from 
Table 2. Simulated average irrigation requirements for the for 12 soil maps units for all years and for the years with different levels of Rainfall/ETo Ratio's using $12.5 \mathrm{~mm}$ irrigation applications.

\begin{tabular}{|c|c|c|c|c|c|c|c|c|c|c|c|c|c|c|c|}
\hline & \multicolumn{12}{|c|}{ Rainfall/ET $\mathrm{E}_{\mathrm{o}}$ Ratio } & \multirow{2}{*}{\multicolumn{3}{|c|}{ All Years }} \\
\hline & \multicolumn{3}{|c|}{$<50 \%$} & \multicolumn{3}{|c|}{$50 \%$ to $60 \%$} & \multicolumn{3}{|c|}{$60 \%$ to $75 \%$} & \multicolumn{3}{|c|}{$>75 \%$} & & & \\
\hline & & & & & & & & Irrigatio & $\mathrm{n}(\mathrm{mm})$ & & & & & & \\
\hline Soil & $\mathrm{N}^{[\mathrm{a}]}$ & Mean & Std Dev & $\mathrm{n}$ & Mean & Std Dev & $\mathrm{n}$ & Mean & Std Dev & $\mathrm{n}$ & Mean & Std Dev & $\mathrm{n}$ & Mean & Std Dev \\
\hline $\mathrm{BnA}$ & 26 & $320 \mathrm{~A}^{[\mathrm{b}]}$ & 38 & 23 & $293 \mathrm{~A}$ & 36 & 23 & $283 \mathrm{~A}$ & 19 & 17 & $215 \mathrm{~A}$ & 37 & 22 & $274 \mathrm{~A}$ & 52 \\
\hline $\mathrm{Cx}$ & 23 & $288 \mathrm{D}$ & 42 & 20 & $250 \mathrm{D}$ & 41 & 19 & $238 \mathrm{DE}$ & 20 & 13 & $163 \mathrm{E}$ & 44 & 18 & $231 \mathrm{~B}$ & 60 \\
\hline Dn & 24 & $298 \mathrm{C}$ & 44 & 21 & $263 \mathrm{C}$ & 42 & 20 & $245 \mathrm{CD}$ & 21 & 15 & $181 \mathrm{D}$ & 41 & 19 & $244 \mathrm{AB}$ & 57 \\
\hline ErA & 24 & $300 \mathrm{C}$ & 42 & 21 & $263 \mathrm{C}$ & 42 & 20 & $245 \mathrm{CD}$ & 21 & 15 & $181 \mathrm{D}$ & 41 & 20 & $244 \mathrm{AB}$ & 57 \\
\hline GoA & 23 & $288 \mathrm{D}$ & 42 & 20 & $250 \mathrm{D}$ & 41 & 19 & $235 \mathrm{E}$ & 19 & 13 & $163 \mathrm{E}$ & 44 & 18 & $230 \mathrm{~B}$ & 60 \\
\hline $\mathrm{NbA}$ & 24 & $300 \mathrm{C}$ & 42 & 21 & $268 \mathrm{C}$ & 37 & 20 & $248 \mathrm{C}$ & 22 & 15 & $192 \mathrm{C}$ & 38 & 20 & $249 \mathrm{AB}$ & 53 \\
\hline $\mathrm{NcA}$ & 26 & $320 \mathrm{~A}$ & 38 & 23 & $293 \mathrm{~A}$ & 36 & 23 & $283 \mathrm{~A}$ & 19 & 17 & $215 \mathrm{~A}$ & 37 & 22 & $274 \mathrm{~A}$ & 52 \\
\hline NfA & 25 & $313 \mathrm{~B}$ & 42 & 22 & $278 \mathrm{~B}$ & 37 & 21 & $260 \mathrm{~B}$ & 24 & 16 & $204 \mathrm{~B}$ & 31 & 21 & $261 \mathrm{AB}$ & 52 \\
\hline $\mathrm{NkA}$ & 25 & $313 \mathrm{~B}$ & 42 & 23 & $283 \mathrm{~B}$ & 34 & 21 & $260 \mathrm{~B}$ & 24 & 17 & $206 \mathrm{AB}$ & 34 & 21 & $263 \mathrm{AB}$ & 52 \\
\hline $\mathrm{NoA}$ & 25 & $318 \mathrm{AB}$ & 40 & 23 & $283 \mathrm{~B}$ & 34 & 21 & $265 \mathrm{~B}$ & 24 & 17 & $208 \mathrm{AB}$ & 37 & 21 & $266 \mathrm{~A}$ & 52 \\
\hline $\mathrm{NrA}$ & 26 & $320 \mathrm{~A}$ & 38 & 23 & $293 \mathrm{~A}$ & 36 & 23 & $283 \mathrm{~A}$ & 19 & 17 & $215 \mathrm{~A}$ & 37 & 22 & $274 \mathrm{~A}$ & 52 \\
\hline $\begin{array}{l}\text { Maximum } \\
\text { Difference }\end{array}$ & & 32.5 & & & 42.5 & & & 47.5 & & & 52.1 & & & 44 & \\
\hline $\begin{array}{l}\text { Maximum } \\
\text { Difference\% }\end{array}$ & & $11 \%$ & & & $17 \%$ & & & $20 \%$ & & & $32 \%$ & & & $19 \%$ & \\
\hline $\begin{array}{l}\text { No. of } \\
\text { Significant } \\
\text { Zones }\end{array}$ & & 4 & & & 4 & & & 5 & & & 5 & & & 2 & \\
\hline
\end{tabular}

$230 \mathrm{~mm}$ for the soils with the highest water holding capacity (WHC) to $274 \mathrm{~mm}$ for the soils with the lowest WHC (table 2). The simulation results produced two groupings (or potential management zones) of significantly different irrigation amount ranges for the soils studied. In these two groups, the four soils with the lowest WHC (BnA, NcA, $\mathrm{NrA}, \mathrm{NoA}$ ) required significantly greater irrigation than the two soils with the highest WHC (Cx, GoA). Irrigation amounts for the other five soils were not significantly different from either grouping.

The simulated years were then divided into years representing different rainfall totals as defined by the Rainfall/ETo ratio. We divided these years into four groups of the Rainfall/ET $\mathrm{ET}_{0}$ ratios representing different degrees of drought conditions and then simulated irrigation amounts for the individual soils (table 2). Irrigation depths for the most severe drought conditions with Rainfall/ET $\mathrm{ET}_{\mathrm{o}}$ ratios less than $50 \%$, ranged from 288 to $320 \mathrm{~mm}$. The irrigation depths for the individual soils resulted in four significantly different groupings or potential management zones. For the Rainfall/ET $\mathrm{ET}_{\mathrm{o}}$ ratio range from $50 \%$ to $60 \%$, the irrigation depths for the individual soils ranged from 250 to $293 \mathrm{~mm}$. Theses irrigation depths resulted in four significantly different and distinct groupings (or potential management zones). The Rainfall/ $/ \mathrm{ET}_{0}$ ratio range from $60 \%$ to $75 \%$ simulations produced irrigation depths ranging from 235 to $283 \mathrm{~mm}$ and resulted in five significantly different groupings (or management zones) with some grouping overlap in the soil with higher WHC. For the Rainfall/ET $\mathrm{ET}_{\mathrm{o}}$ ratio greater than $75 \%$, the irrigation depths ranged from 163 to $215 \mathrm{~mm}$ and produced five significantly different groupings (or management zones) with some grouping overlap for the soils with lower WHC. In considering the Rainfall/ET $\mathrm{E}_{\mathrm{o}}$ ratio in the simulations, four to five management zones were identified compared to only two when simulating the entire period. As expected, in years with greater rainfall, irrigation depths were less for all soils. In years with the lowest Rainfall/ETo ratio, differences in irrigation depths between the soil with the least WHC and the soil with the greatest WHC were lower compared to the years with the higher Rainfall/ETo ratios. This would correspond to the soil with the lower WHC being depleted more frequently and needing more frequent irrigations. The overall difference in water applications over the 21-year simulation period between soil management zones was approximately $19 \%$. The difference in water applications between soil management zones ranged from $11 \%$ to $32 \%$ as the Rainfall/ $\mathrm{ET}_{\text {o }}$ ratio increased due to the increased utilization of rainfall in the soils with greater WHC.

To evaluate the potential water conservation, we utilized the results of simulations of the individual soils to simulate the potential water savings using defined management zones based on soil WHC versus using UI (table 3). The field was simulated using a UI based on the soil type with the greatest field area. For simulations based on management zones, the field was divided into two and four management zones based on the WHC of the soils as previously described. The simulation of the UI produced a mean irrigation application of $263 \mathrm{~mm}$ for the entire period. The irrigation application for the lowest to highest rainfall/ET $\mathrm{ET}_{\mathrm{o}}$ ratios ranged from 313 to 206 with greater irrigation being required during the years with the lowest rainfalls.

For the two-management zone simulation, the mean irrigation depths for the soils with the lower WHC was $274 \mathrm{~mm}$ and for the higher WHC soils was $250 \mathrm{~mm}$. For the two management zones, the differences in water application depths between management zones ranged from $6 \%$ to $14 \%$.

For the four-management zone simulations, the application depths were 274, 266, 257, and $244 \mathrm{~mm}$, respectively, for the lowest WHC zone to the highest WHC zone. The irrigation application depths for the simulations with the Rainfall/ET $T_{0}$ ratios produced differences between the irrigation application depths ranging from 20 to $37.5 \mathrm{~mm}$. Results from 
Table 3. Simulated average irrigation requirements for a uniform irrigation with one management zone, two management zones and four management zones for all years and for the years with different levels of Rainfall/ET $\mathbf{~}_{0}$ Ratio's using $12.5 \mathrm{~mm}$ irrigation applications.

\begin{tabular}{|c|c|c|c|c|c|c|c|c|c|c|c|}
\hline \multirow{4}{*}{$\begin{array}{c}\text { Management } \\
\text { Zones }\end{array}$} & \multirow{4}{*}{$\begin{array}{c}\text { Management } \\
\text { Zone }\end{array}$} & \multicolumn{8}{|c|}{ Rainfall/ET ${ }_{0}$ Ratio } & \multirow{2}{*}{\multicolumn{2}{|c|}{ All Years }} \\
\hline & & \multicolumn{2}{|c|}{$<50 \%$} & \multicolumn{2}{|c|}{$50 \%$ to $60 \%$} & \multirow{2}{*}{\multicolumn{2}{|c|}{$\begin{array}{c}60 \% \text { to } 75 \% \\
\text { Irrigation }(\mathrm{mm})\end{array}$}} & \multicolumn{2}{|c|}{$>75 \%$} & & \\
\hline & & & & & & & & & & \multicolumn{2}{|c|}{ 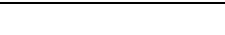 } \\
\hline & & Mean & Std Dev & Mean & Std Dev & Mean & Std Dev & Mean & Std Dev & Mean & Std Dev \\
\hline One & 1 & 313 & 38 & 283 & 31 & 260 & 22 & 206 & 32 & 263 & 51 \\
\hline \multirow[t]{3}{*}{ Two } & 1 & 320 & 35 & 293 & 33 & 283 & 17 & 215 & 34 & 274 & 50 \\
\hline & 2 & 303 & 44 & 270 & 33 & 248 & 20 & 192 & 35 & 250 & 54 \\
\hline & Maximum Difference & 17 & & 23 & & 35 & & 23 & & 24 & \\
\hline \multirow[t]{5}{*}{ Four } & 1 & 320 & 35 & 293 & 33 & 283 & 18 & 215 & 34 & 274 & 51 \\
\hline & 2 & 318 & 37 & 283 & 31 & 265 & 22 & 210 & 34 & 266 & 51 \\
\hline & 3 & 310 & 44 & 273 & 36 & 253 & 26 & 204 & 31 & 257 & 51 \\
\hline & 4 & 300 & 39 & 263 & 38 & 245 & 19 & 181 & 38 & 244 & 56 \\
\hline & Maximum Difference & 20 & & 30 & & 38 & & 34 & & 30 & \\
\hline
\end{tabular}

the four-management zone simulations produced differences in irrigation application depths ranging from $7 \%$ to $18 \%$ between the management zones.

\section{SCEnario 2, Refill SoIl Profile to Field CaPaCity}

The simulations were repeated with irrigation applications to fill the soil profile to field capacity. The simulation results for the individual soils over the 21 -year period produced irrigation amounts greater than in scenario 1; irrigation amounts ranged from 276 to $303 \mathrm{~mm}$ (table 4). Irrigating to fill the soil profile resulted in approximately $50 \%$ fewer overall irrigation events than using the $12.5 \mathrm{~mm}$ application depths in Scenario 1. The simulation results produced only one grouping (or potential management zone) over the 21year period.

Irrigation depths for Rainfall/ET $\mathrm{ET}_{\mathrm{o}}$ ratios less than $50 \%$ ranged from 340 to $350 \mathrm{~mm}$ and resulted in one grouping or potential management zone. For the Rainfall/ET $\mathrm{ET}_{0}$ ratio range from $50 \%$ to $60 \%$, the irrigation depths for the individual soils ranged from 285 to $322 \mathrm{~mm}$ and resulted in three significantly different and distinct groupings (or potential management zones). The Rainfall/ $/ \mathrm{ET}_{\mathrm{o}}$ ratio range from $60 \%$ to $75 \%$ simulations produced irrigation depths ranging from 277 to $310 \mathrm{~mm}$ and resulted in four significantly different groupings (or management zones). For the Rainfall/ET $\mathrm{ET}_{0}$ ratio greater than $75 \%$, the irrigation depths ranged from 211 to $253 \mathrm{~mm}$ and produced four significantly different groupings (or management zones). The overall 21-year difference in water application depths was approximately $10 \%$ between soil management zones. The difference in water applications between soil management zones ranged from $5 \%$ to $18 \%$ as the Rainfall/ET $/ \mathrm{T}_{\mathrm{o}}$ ratio increased due to the increased utilization of rainfall in the soils with greater WHC.

Field simulations based on two and four management zones as previously described were compared to UI (table 5). The simulation of the UI produced a mean irrigation application of $295 \mathrm{~mm}$ for the entire period. The irrigation application for the lowest to highest rainfall/ET $\mathrm{ET}_{\mathrm{o}}$ ratios ranged from 330 to $232 \mathrm{~mm}$. For the two-management zone simulation, the mean irrigation depths for the soils with the lower WHC was $295 \mathrm{~mm}$ and for the higher WHC soils was 286 $\mathrm{mm}$. Differences between the application depths for the two management zones for the rainfall/ET $\mathrm{ET}_{\mathrm{o}}$ ratio ranged from 0 to $25 \mathrm{~mm}$. For the four-management zone simulations, the overall management zone irrigation applications were 305 , 295, 286, and $285 \mathrm{~mm}$, respectively for the lowest WHC zone to the highest WHC zone. The irrigation applications for the simulations with the Rainfall/ET o ratios produced

Table 4. Simulated average irrigation requirements to refill the soil profile to field capacity for the 12 soil maps units for all years and for the years with different levels of Rainfall/ET Ratio's. $_{0}$

\begin{tabular}{|c|c|c|c|c|c|c|c|c|c|c|c|c|c|c|c|}
\hline \multirow[b]{4}{*}{ Soil } & \multicolumn{12}{|c|}{ Rainfall/ET ${ }_{0}$ Ratio } & \multirow{2}{*}{\multicolumn{3}{|c|}{ All Years }} \\
\hline & \multicolumn{3}{|c|}{$<50 \%$} & \multicolumn{3}{|c|}{$50 \%$ to $60 \%$} & \multicolumn{3}{|c|}{$60 \%$ to $75 \%$} & \multicolumn{3}{|c|}{$>75 \%$} & & & \\
\hline & \multirow[b]{2}{*}{$\mathrm{n}^{[\mathrm{a}]}$} & \multicolumn{2}{|c|}{ Irrigation (mm) } & \multirow[b]{2}{*}{$\mathrm{n}$} & \multicolumn{2}{|c|}{ Irrigation (mm) } & \multirow[b]{2}{*}{$\mathrm{n}$} & \multicolumn{2}{|c|}{$\begin{array}{l}\text { Irrigation } \\
(\mathrm{mm})\end{array}$} & \multirow[b]{2}{*}{$\mathrm{n}$} & \multicolumn{2}{|c|}{$\begin{array}{l}\text { Irrigation } \\
(\mathrm{mm})\end{array}$} & \multirow[b]{2}{*}{$\mathrm{n}$} & \multicolumn{2}{|c|}{$\begin{array}{c}\text { Irrigation } \\
(\mathrm{mm})\end{array}$} \\
\hline & & Mean & Std Dev & & Mean & Std Dev & & Mean & Std Dev & & Mean & Std Dev & & Mean & Std Dev \\
\hline $\mathrm{BnA}$ & 15 & $349 \mathrm{~A}^{[\mathrm{b}]}$ & 47 & 13 & $319 \mathrm{AB}$ & 28 & 13 & $308 \mathrm{~A}$ & 20 & 10 & $247 \mathrm{AB}$ & 27 & 13 & $303 \mathrm{~A}$ & 49 \\
\hline $\mathrm{Cx}$ & 9 & $339 \mathrm{~A}$ & 37 & 8 & $285 \mathrm{C}$ & 31 & 8 & $279 \mathrm{D}$ & 40 & 6 & $211 \mathrm{C}$ & 39 & 7 & $275 \mathrm{~A}$ & 59 \\
\hline Dn & 10 & $340 \mathrm{~A}$ & 51 & 9 & $301 \mathrm{BC}$ & 36 & 9 & $284 \mathrm{BCD}$ & 38 & 7 & $227 \mathrm{BC}$ & 43 & 9 & $285 \mathrm{~A}$ & 58 \\
\hline ErA & 10 & $336 \mathrm{~A}$ & 49 & 9 & $300 \mathrm{BC}$ & 35 & 9 & $280 \mathrm{BCD}$ & 37 & 7 & $227 \mathrm{BC}$ & 43 & 9 & $283 \mathrm{~A}$ & 56 \\
\hline GoA & 9 & $338 \mathrm{~A}$ & 42 & 8 & $288 \mathrm{C}$ & 33 & 7 & $278 \mathrm{D}$ & 31 & 6 & $214 \mathrm{C}$ & 42 & 7 & $276 \mathrm{~A}$ & 58 \\
\hline $\mathrm{NbA}$ & 11 & $340 \mathrm{~A}$ & 42 & 9 & $296 \mathrm{C}$ & 34 & 9 & $291 \mathrm{ABCD}$ & 26 & 7 & $230 \mathrm{ABC}$ & 41 & 9 & $286 \mathrm{~A}$ & 53 \\
\hline $\mathrm{NcA}$ & 14 & $351 \mathrm{~A}$ & 41 & 13 & $319 \mathrm{AB}$ & 29 & 13 & $310 \mathrm{~A}$ & 22 & 10 & $252 \mathrm{AB}$ & 31 & 13 & $305 \mathrm{~A}$ & 48 \\
\hline NfA & 12 & $341 \mathrm{~A}$ & 38 & 11 & $317 \mathrm{AB}$ & 27 & 11 & $299 \mathrm{ABC}$ & 37 & 9 & $247 \mathrm{AB}$ & 48 & 11 & $298 \mathrm{~A}$ & 51 \\
\hline $\mathrm{NkA}$ & 12 & $333 \mathrm{~A}$ & 37 & 12 & $321 \mathrm{~A}$ & 28 & 11 & $291 \mathrm{ABCD}$ & 31 & 9 & $246 \mathrm{AB}$ & 35 & 11 & $295 \mathrm{~A}$ & 47 \\
\hline NoA & 13 & $338 \mathrm{~A}$ & 54 & 12 & $323 \mathrm{~A}$ & 29 & 11 & $301 \mathrm{AB}$ & 40 & 10 & $253 \mathrm{~A}$ & 32 & 11 & $302 \mathrm{~A}$ & 50 \\
\hline $\mathrm{NrA}$ & 14 & $351 \mathrm{~A}$ & 41 & 13 & $319 \mathrm{AB}$ & 29 & 13 & $310 \mathrm{~A}$ & 22 & 10 & $252 \mathrm{AB}$ & 31 & 13 & $305 \mathrm{~A}$ & 48 \\
\hline Maximum difference & & 18 & & & 38 & & & 33 & & & 42 & & & 30 & \\
\hline Maximum difference $\%$ & & $5 \%$ & & & $13 \%$ & & & $11 \%$ & & & $18 \%$ & & & $10 \%$ & \\
\hline No. of significant zones & & 1 & & & 3 & & & 4 & & & 4 & & & 1 & \\
\hline
\end{tabular}

[a] Average number of irrigations per year.

[b] Irrigation depths in a column with a different letter was significantly different at the $95 \%$ level. 
Table 5. Simulated number of irrigations and irrigation requirements to refill the soil profile to field capacity for a uniform irrigation with one management zone, two management zones and four management zones for all years and for the years with different levels of Rainfall/ET Ratio's.

\begin{tabular}{|c|c|c|c|c|c|c|c|c|c|c|c|c|c|c|c|c|}
\hline \multirow{4}{*}{$\begin{array}{c}\text { Management } \\
\text { Zones }\end{array}$} & \multirow{4}{*}{$\begin{array}{c}\text { Sub-Management } \\
\text { Zone }\end{array}$} & \multicolumn{12}{|c|}{ Rainfall/ET $\mathrm{ET}_{\mathrm{o}}$ Ratio } & & & \\
\hline & & \multicolumn{3}{|c|}{$<50 \%$} & \multicolumn{3}{|c|}{$50 \%$ to $60 \%$} & \multicolumn{3}{|c|}{$60 \%$ to $75 \%$} & \multicolumn{3}{|c|}{$>75 \%$} & \multicolumn{3}{|c|}{ All Years } \\
\hline & & \multicolumn{3}{|c|}{ Irrigation } & \multicolumn{3}{|c|}{ Irrigation } & \multicolumn{3}{|c|}{ Irrigation } & \multicolumn{3}{|c|}{ Irrigation } & \multicolumn{3}{|c|}{ Irrigation } \\
\hline & & $\mathrm{N}^{[\mathrm{a}]}$ & Mean & Std Dev & $\mathrm{n}$ & Mean & Std Dev & $\mathrm{n}$ & Mean & Std Dev & $\mathrm{n}$ & Mean & Std Dev & $\mathrm{n}$ & Mean & Std Dev \\
\hline One & 1 & 13 & 330 & 34 & 12 & 321 & 25 & 12 & 291 & 28 & 10 & 246 & 32 & 12 & 295 & 46 \\
\hline \multirow[t]{3}{*}{ Two } & 1 & 12 & 333 & 34 & 12 & 321 & 25 & 11 & 291 & 28 & 9 & 246 & 32 & 11 & 295 & 46 \\
\hline & 2 & 11 & 340 & 38 & 9 & 296 & 31 & 9 & 291 & 24 & 7 & 230 & 38 & 9 & 286 & 52 \\
\hline & Max Difference (mm) & & 7 & & & 25 & & & 0 & & & 16 & & & 9 & \\
\hline \multirow[t]{5}{*}{ Four } & 1 & 14 & 351 & 38 & 13 & 319 & 27 & 13 & 310 & 20 & 10 & 252 & 29 & 13 & 305 & 47 \\
\hline & 2 & 12 & 333 & 35 & 12 & 321 & 26 & 11 & 291 & 28 & 9 & 246 & 33 & 11 & 295 & 46 \\
\hline & 3 & 11 & 340 & 42 & 9 & 296 & 34 & 9 & 291 & 26 & 7 & 230 & 41 & 9 & 286 & 53 \\
\hline & 4 & 10 & 340 & 47 & 9 & 301 & 33 & 9 & 284 & 35 & 7 & 227 & 40 & 9 & 285 & 57 \\
\hline & Max Difference $(\mathrm{mm})$ & & 17 & & & 25 & & & 26 & & & 25 & & & 20 & \\
\hline
\end{tabular}

[a] Average number of irrigations per year.

similar results with difference between the irrigation applications ranging from 17 and $26 \mathrm{~mm}$.

When considering the field area for the irrigation management zones, the potential overall 21-year irrigation water savings using the soil area-specific calculations resulted in water usages in the two and four management zone simulations of $-3.3 \%$ and $0.4 \%$, respectively (tables 6 and 7 ). For the years with the Rainfall/ET $/ T_{0}$ ratios, the water savings for the two-management zone simulation ranged from $-6.8 \%$ to $1.1 \%$. Similarly, for the four-management zone simulation the water savings ranged from $1.2 \%$ to $-5.8 \%$. Individual soils simulations compared to uniform irrigation simulations (table 8 and 9) resulted in an overall water savings of $-1.7 \%$ to $-0.8 \%$ and for the years with the different Rainfall/ $/ \mathrm{ET}_{\mathrm{o}}$ ratios ranged from $-3.4 \%$ to $1.4 \%$.

Table 6. Simulated irrigation requirements for different management zones and calculated soil area weighted water savings using $12.5 \mathrm{~mm}$ irrigation applications. Water savings calculated based on uniform/one zone irrigation using the soil with the greatest field area. Rainfall/ET $\mathrm{ET}_{0}$ Ratio

\begin{tabular}{|c|c|c|c|c|c|c|}
\hline \multirow{3}{*}{$\begin{array}{l}\text { Management } \\
\text { Zones }\end{array}$} & \multirow{3}{*}{$\begin{array}{c}\text { Sub-Management } \\
\text { Zone }\end{array}$} & $<50 \%$ & $50 \%$ to $60 \%$ & $60 \%$ to $75 \%$ & $>75 \%$ & All Years \\
\hline & & \multicolumn{5}{|c|}{ Irrigation Water Volume $\left(\mathrm{m}^{3}\right)$} \\
\hline & & Mean & Mean & Mean & Mean & Mean \\
\hline One & 1 & 17786 & 16078 & 14797 & 11737 & 14941 \\
\hline \multirow{4}{*}{ Two } & 1 & 15747 & 14393 & 13901 & 10559 & 13501 \\
\hline & 2 & 2331 & 2081 & 1907 & 1477 & 1927 \\
\hline & Total & 18078 & 16474 & 15808 & 12036 & 15429 \\
\hline & Water savings & $-1.6 \%$ & $-2.5 \%$ & $-6.8 \%$ & $-2.6 \%$ & $-3.3 \%$ \\
\hline \multirow{6}{*}{ Four } & 1 & 6438 & 5885 & 5683 & 4317 & 5520 \\
\hline & 2 & 9309 & 8508 & 8218 & 6242 & 7982 \\
\hline & 3 & 898 & 790 & 732 & 592 & 745 \\
\hline & 4 & 1442 & 1262 & 1176 & 871 & 1173 \\
\hline & Total & 18,087 & 16445 & 15809 & 12022 & 15420 \\
\hline & Water savings & $-1.7 \%$ & $-2.3 \%$ & $-6.8 \%$ & $-2.4 \%$ & $-3.2 \%$ \\
\hline
\end{tabular}

Table 7. Simulated irrigation requirements to refill soil profile to field capacity for a uniform irrigation with one management zone, two management zones and four management zones for all years and for the years with different levels of Rainfall/ET $\mathbf{R}_{0}$ Ratio's.

\begin{tabular}{|c|c|c|c|c|c|c|}
\hline \multirow{4}{*}{$\begin{array}{l}\text { Management } \\
\text { Zones }\end{array}$} & \multirow{4}{*}{$\begin{array}{l}\text { Sub-Management } \\
\text { Zone }\end{array}$} & \multicolumn{4}{|c|}{ Rainfall/ET $\mathrm{ET}_{\mathrm{o}}$ Ratio } & \multirow[b]{2}{*}{ All Years } \\
\hline & & $<50 \%$ & $50 \%$ to $60 \%$ & $60 \%$ to $75 \%$ & $>75 \%$ & \\
\hline & & \multicolumn{5}{|c|}{ Irrigation Water Volume $\left(\mathrm{m}^{3}\right)$} \\
\hline & & Mean & Mean & Mean & Mean & Mean \\
\hline One & 1 & 18953 & 18280 & 16557 & 14001 & 16807 \\
\hline \multirow{4}{*}{ Two } & 1 & 16388 & 15805 & 14315 & 12105 & 14532 \\
\hline & 2 & 2618 & 2278 & 2242 & 1773 & 2206 \\
\hline & Total & 19006 & 18083 & 16557 & 13878 & 16738 \\
\hline & Water Savings & $-0.3 \%$ & $1.1 \%$ & $0.0 \%$ & $0.9 \%$ & $0.4 \%$ \\
\hline \multirow{6}{*}{ Four } & 1 & 7,066 & 6409 & 6242 & 5062 & 6141 \\
\hline & 2 & 9688 & 9343 & 8462 & 7156 & 8591 \\
\hline & 3 & 985 & 857 & 843 & 667 & 830 \\
\hline & 4 & 1634 & 1448 & 1363 & 1091 & 1370 \\
\hline & Total & 19373 & 18057 & 16910 & 13976 & 16932 \\
\hline & Water Savings & $-2.2 \%$ & $1.2 \%$ & $-2.1 \%$ & $0.2 \%$ & $-0.7 \%$ \\
\hline
\end{tabular}


Table 8. Simulated irrigation requirements for different management zones and calculated soil area weighted water savings for each soil type using $12.5 \mathrm{~mm}$ irrigation applications. ${ }^{\text {[a] }}$

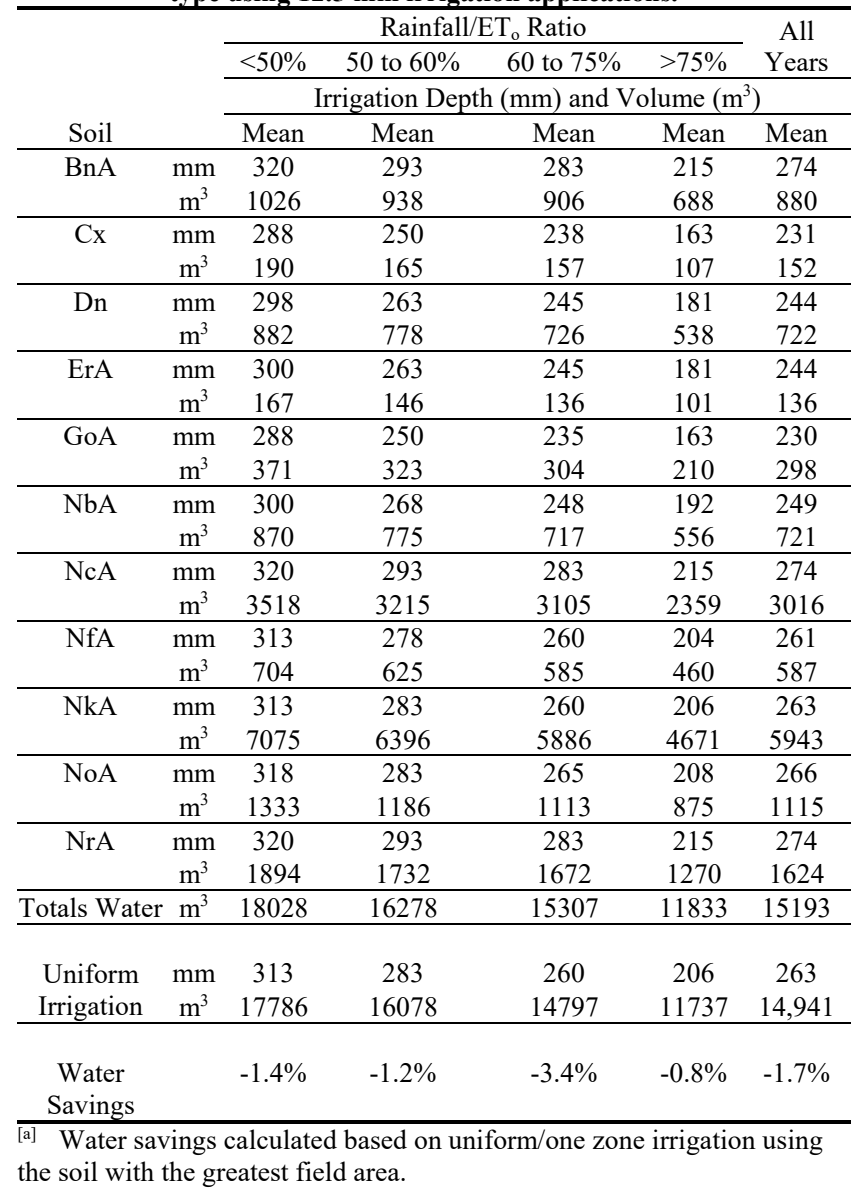

In fields with equal size soil areas, the comparison of application depths among management zones may be appropriate and result in potential water savings. However, in this case using actual field soil areas in calculating total water applied resulted in slightly greater water use compared to uniform irrigation management. In previous studies (NiJbroek et al., 2003; King et al., 2006) little to no irrigation water savings were observed. Evans and King (2012) reported that most water savings in VRI could be attributed to turning off water application in specific field areas (wetlands, ditches, etc.) In our simulations, the entire field was assumed to be in crop production and each soil had the same potential productivity, which may not be the case in some soils.

\section{SUMmARY AND CONCLUSIONS}

The potential water savings from site-specific variablerate irrigation (VRI) management was evaluated using soilspecific water balance simulations. The simulations were carried out using a 21-year weather record on a field with 12 soils mapping units that had a $65 \%$ difference in water holding capacities. Over the entire 21-year simulation period, the individual soils receiving a $12.5 \mathrm{~mm}$ per irrigation produced only two groupings of soils that had significant dif-
Table 9. Simulated irrigation requirements to refill soil profile to field capacity for different management zones and calculated soil area weighted water savings for each soil type. ${ }^{[a]}$

\begin{tabular}{|c|c|c|c|c|c|c|}
\hline \multirow[b]{3}{*}{ Soil } & & \multicolumn{4}{|c|}{ Rainfall/ET ${ }_{0}$ Ratio } & \multirow{2}{*}{$\begin{array}{c}\text { All } \\
\text { Years }\end{array}$} \\
\hline & & $<50 \%$ & 50 to $60 \%$ & 60 to $75 \%$ & $>75 \%$ & \\
\hline & & \multicolumn{5}{|c|}{ Irrigation Depth $(\mathrm{mm})$ and Volume $\left(\mathrm{m}^{3}\right)$} \\
\hline \multirow[t]{2}{*}{$\mathrm{BnA}$} & $\mathrm{mm}$ & 349 & 319 & 308 & 247 & 303 \\
\hline & $\mathrm{m}^{3}$ & 1119 & 1021 & 987 & 792 & 971 \\
\hline \multirow[t]{2}{*}{$\mathrm{Cx}$} & $\mathrm{mm}$ & 339 & 285 & 279 & 211 & 275 \\
\hline & $\mathrm{m}^{3}$ & 223 & 188 & 184 & 139 & 181 \\
\hline \multirow[t]{2}{*}{ Dn } & $\mathrm{mm}$ & 340 & 301 & 284 & 227 & 285 \\
\hline & $\mathrm{m}^{3}$ & 223 & 188 & 184 & 139 & 181 \\
\hline \multirow[t]{2}{*}{ ErA } & $\mathrm{mm}$ & 336 & 300 & 280 & 227 & 283 \\
\hline & $\mathrm{m}^{3}$ & 187 & 167 & 156 & 126 & 157 \\
\hline \multirow[t]{2}{*}{ GoA } & $\mathrm{mm}$ & 338 & 288 & 278 & 214 & 276 \\
\hline & $\mathrm{m}^{3}$ & 437 & 372 & 358 & 276 & 357 \\
\hline \multirow[t]{2}{*}{$\mathrm{NbA}$} & $\mathrm{mm}$ & 340 & 296 & 291 & 230 & 286 \\
\hline & $\mathrm{m}^{3}$ & 437 & 372 & 358 & 276 & 357 \\
\hline \multirow[t]{2}{*}{$\mathrm{NcA}$} & $\mathrm{mm}$ & 351 & 319 & 310 & 252 & 305 \\
\hline & $\mathrm{m}^{3}$ & 3861 & 3502 & 3410 & 2766 & 3355 \\
\hline \multirow[t]{2}{*}{$\mathrm{NfA}$} & $\mathrm{mm}$ & 341 & 317 & 299 & 247 & 298 \\
\hline & $\mathrm{m}^{3}$ & 768 & 713 & 673 & 557 & 672 \\
\hline \multirow[t]{2}{*}{$\mathrm{NkA}$} & $\mathrm{mm}$ & 333 & 321 & 291 & 246 & 295 \\
\hline & $\mathrm{m}^{3}$ & 7540 & 7271 & 6586 & 5569 & 6686 \\
\hline \multirow[t]{2}{*}{ NoA } & $\mathrm{mm}$ & 338 & 323 & 301 & 253 & 302 \\
\hline & $\mathrm{m}^{3}$ & 1420 & 1356 & 1264 & 1064 & 1266 \\
\hline \multirow[t]{2}{*}{$\mathrm{NrA}$} & $\mathrm{mm}$ & 351 & 319 & 310 & 252 & 305 \\
\hline & $\mathrm{m}^{3}$ & 2079 & 1886 & 1837 & 1489 & 1807 \\
\hline Total Water & $\mathrm{m}^{3}$ & 19401 & 18026 & 16950 & 13967 & 16938 \\
\hline Uniform & $\mathrm{mm}$ & 333 & 321 & 291 & 246 & 295 \\
\hline Irrigation & $\mathrm{m}^{3}$ & 18953 & 18280 & 16557 & 14001 & 16807 \\
\hline $\begin{array}{c}\text { Water } \\
\text { Savings }\end{array}$ & & $-2.4 \%$ & $1.4 \%$ & $-2.4 \%$ & $0.2 \%$ & $-0.8 \%$ \\
\hline
\end{tabular}
the soil with the greatest field area.

ferences in irrigation water applications depths. Applying irrigation to restore the soil profile to field capacity resulted in fewer irrigations and only 1 grouping or management zone. Averaging irrigation application depths over the entire simulation period masked the impact of weather variability. To address the impact of weather variability, a more in-depth evaluation that was conducted sub-dividing the simulation period into years with different degrees of rainfall/ETo ratios, resulted in 4 and 5 distinct groupings (or potential management zones) for the $12.5 \mathrm{~mm}$ simulations and 1 to 4 groupings with the field capacity irrigations. These simulation results indicate that VRI system design and management should not be solely based on long term average weather conditions but should utilize differing weather conditions when greater irrigation may be required to identify potential management zones for VRI systems. The simulations produced irrigation application depth differences between management zones from $11 \%$ to $32 \%$ for the 12.5 irrigations and from $5 \%$ to $18 \%$ for the field capacity irrigations. The greater irrigation application depth differences for the 12.5 $\mathrm{mm}$ irrigations were because irrigations only partially refilled the soil profile which required more frequent irrigations. Using these results, two and four management zones were simulated to compare uniform irrigation to spatial VRI applications. For the entire simulation period, the two management zone simulations averaged 0 to $3 \%$ less irrigation based on application depth while the four management zone 
simulations used $3 \%$ more to $3 \%$ less compared to uniform irrigation. For simulations with different degrees of rainfall/ET ratios, the two management zone simulations averaged from $3 \%$ more to $8 \%$ less irrigation across management zones while the four management zones averaged from $7 \%$ more to $8 \%$ less irrigation compared to uniform irrigations. However, when the field areas for the individual soils and management zones were accounted for, greater irrigation volumes were calculated for VRI irrigations compared to uniform irrigation. Water usage increased from $1.6 \%$ to $6.8 \%$ in the 12.5 irrigations and from $-1.2 \%$ to $2.2 \%$ for the field capacity irrigations. Soils with the lowest WHC required irrigation more frequently and had higher irrigation application depths and volumes. These simulation results demonstrate that the large difference in soil water holding capacities in a field may be mitigated by the individual soil areas on the total irrigation volumes required. Both the soil field areas and WHC's should be utilized in developing VRI management zones. For other fields, water usage may vary depending on the soil type properties, variability, and spatial area as well as the soils' productivity potential.

\section{REFERENCES}

Al-Kufaishi, S. A., Blackmore, B. S., \& Sourell, H. (2006). The feasibility of using variable rate water application under a central pivot irrigation system. Irrig. Drain. Syst., 20(2-3), 317-327. https://doi.org/10.1007/s10795-006-9010-2

Allen, R. G., Pereira, L. S., Raes, D., \& Smith, M. (1998). Crop evapotranspiration: Guidelines for computing crop water requirements. Irrigation and Drainage Paper No. 56. Rome, Italy: United Nations FAO.

Allen, R. G., Walter, I. A., Elliott, R. L., Howell, T. A., Itenfisu, D., Jensen, M. E., \& Snyder, R. L. (2005). The ASCE standardized reference evapotranspiration equation. ASCE.

Evans, R. G., \& King, B. A. (2012). Site-specific sprinkler irrigation in a water-limited future. Trans. ASABE, 55(2), 493-504. https://doi.org/10.13031/2013.41382

Evans, R. G., LaRue, J., Stone, K. C., \& King, B. A. (2013). Adoption of site-specific variable rate sprinkler irrigation systems. Irrig. Sci., 31(4), 871-887. https://doi.org/10.1007/s00271-012-0365-x

Hedley, C. B., \& Yule, I. J. (2009). Soil water status mapping and two variable-rate irrigation scenarios. Precis. Agric., 10(4), 342355. https://doi.org/10.1007/s11119-009-9119-z
Jones, J. W., Hoogenboom, G., Porter, C. H., Boote, K. J., Batchelor, W. D., Hunt, L. A.,... Ritchie, J. T. (2003). The DSSAT cropping system model. Eur. J. Agron., 18(3), 235-265. https://doi.org/10.1016/S1161-0301(02)00107-7

King, B. A., Stark, J. C., \& Wall, R. W. (2006). Comparison of sitespecific and conventional uniform irrigation management for potatoes. Appl. Eng. Agric., 22(5), 677-688. https://doi.org/10.13031/2013.22000

Nijbroek, R., Hoogenboom, G., \& Jones, J. W. (2003). Optimizing irrigation management for a spatially variable soybean field. Agric. Syst., 76(1), 359-377. https://doi.org/10.1016/S0308521X(02)00127-0

Peele, T. C., Beale, O. W., \& Lesesne, F. F. (1970). The physical properties of some South Carolina soils. Tech. Bull. 1037. Clemson: South Carolina Agricultural Experiment Station, Clemson University.

Ritchie, J. T., \& Amato, M. (1990). Field evaluation of plant extractable soil water for irrigation scheduling. Acta Hortic., 278, 595-615. https://doi.org/10.17660/ActaHortic.1990.278.59

Sadler, E. J., Camp, C. R., Evans, D. E., \& Millen, J. A. (2002). Spatial variation of corn response to irrigation. Trans. ASAE, 45(6), 1869-1881. https://doi.org/10.13031/2013.11438

Sadler, E. J., Evans, R. G., Stone, K. C., \& Camp, C. R. (2005). Opportunities for conservation with precision irrigation. JSWC, 60(6), 371-378. Retrieved from http://www.jswconline.org/content/60/6/371.abstract

Sadler, E. J., Gerwig, B. K., Evans, D. E., Busscher, W. J., \& Bauer, P. J. (2000). Site-specific modeling of corn yield in the SE Coastal Plain. Agric. Syst., 64(3), 189-207. https://doi.org/10.1016/S0308-521X(00)00022-6

Stone, K. C., Hunt, P. G., Cantrell, K. B., \& Ro, K. S. (2010). The potential impacts of biomass feedstock production on water resource availability. Bioresour. Technol., 101(6), 2014-2025. https://doi.org/10.1016/j.biortech.2009.10.037

Sui, R., \& Yan, H. (2017). Field study of variable rate irrigation management in humid climates. Irrig. Drain., 66(3), 327-339. https://doi.org/10.1002/ird.2111

USDA-SCS. (1984). Classification and correlation of the soils of the Coastal Plain Research Center, ARS, Florence, South Carolina, South National Technical Center, Fort Worth, TX: USDA-SCS. 